ARTIKEL

\title{
SIKAP WARGA PESANTREN TENTANG FENOMENA RADIKALISME AGAMA
}

\author{
Dilan Imam Adilan \\ Program Studi Religious Studies \\ Program Pascasarjana UIN Sunan Gunung Djati Bandung \\ dilan.imam@gmail.com
}

\begin{abstract}
This study focuses on the views and attitudes of Pesantren residents about the religious radicalism-fundamentalism phenomena in two tahfir. (Qur'anic memorized) pesantrens in Bandung. This descriptive-analytical study employs data collection through interviews, document research, and observation. The result of the study is that about the relationship between views and attitudes, the two pesantren citizens carried a moderate paradigm. They tend to try to integrate views that are antagonistic in looking at Islamic relations and social issues. Also they wanted to soften the conservative paradigm that is the light of religious fundamentalism-views and attitudes, which often make a generalization that Islam has opinion that is inseparable from the modernization and progress of the times.
\end{abstract}

Keywords: Radicalism, Fundamentalism, Pesantren, Religious Phenomena

\begin{abstract}
Abstrak
Penelitian ini berfokus pada pandangan dan sikap warga Pesantren tentang fenomena radikalisme agama-fundamentalisme di dua pesantren tahfiz (hafalan alQur'an) di Bandung. Penelitian deskriptif analitis ini menggunakan pengumpulan data melalui wawancara, penelitian dokumen, dan observasi. Hasil dari penelitian ini adalah bahwa antara pandangan dan sikap, dua warga pesantren membawa paradigma yang moderat. Mereka cenderung mencoba untuk mengintegrasikan pandanganpandangan yang bertentangan dalam memandang hubungan-hubungan Islam dan masalah-masalah sosial. Mereka juga ingin melunakkan paradigma konservatif yang merupakan cahaya pandangan dan sikap fundamentalisme agama, yang sering membuat generalisasi bahwa Islam memiliki hubungan atau hubungan yang tidak dapat dilepaskan dari modernisasi dan kemajuan zaman.
\end{abstract}

Kata Kunci: Radikalisme, Fundamentalisme, Pesantren, Fenomena Keagamaan 


\section{A. Pendahuluan}

Fundamentalisme-radikalisme Agama kembali diperbincangkan setelah beberapa kejadian terakhir aksi teror bom di Surabaya dan Sidoarjo pada tanggal 13 Mei 2018 dan selang dua hari setelahnya 15 Mei 2018. ${ }^{1}$ Aksi terorisme yang menyasar gereja ini menciptakan ketakutan luar biasa bagi pemeluk antar umat beragama. Menjauhkan nilai dan cita akan kehidupan beragama yang toleran dan damai. Semakin mendapat titik terang saat di identifikasi sementara di duga para pelaku teroris itu satu keluarga yang memiliki pemahaman agama yang kuat.

Menelusuri jejak pemahaman fundamentalisme-radikalisme ini dalam lintas kesejarahan agama-agama dunia, benturan antar agama, modernisasi serta sekulerisasi. Fenomena aksi kekerasan dan terorisme salah satu penyebabnya ialah konflik sektarian berbasiskan ideologi keagamaan.Penyimpangan pemahaman keagamaan dari sudut internal, dan pengaruh sosio-politik dari sudut eksternal. Teror dan aksi anarkisme yang mengorbankan umat manusia sesunguhnya tidak bisa lepas dari pandangan dan sikap orang yang beragama.

Terjadinya fundamentalisme-radikalisme agama merupakan akumulasi pandangan dan sikap orang beragama terkait konstruksi keagamaan. Dalam hal ini paham atau ajaran agama yang diusung atau diperankan oleh suatu komunitas atau lembaga pendidikan islam. Maka hari ini, yang terjadi adalah legitimasi kekerasan yang dijustifikasi secara teologis seperti istilah jihad fi sabilillah. Mereka meyakini dan merasa absah melakukan tindakan kekerasan dengan mengatasnamakan agama dan Tuhan $^{2}$, yang kesemuanya itu berawal dari perkembangan dan perubahan dari sistem keagamaan.

Bagi kaum Muslimin ketidakberubahan merupakan suatu idaman bagi individu maupun masyarakat manusia. ${ }^{3}$ Gagasan tentang perkembangan "agama”

\footnotetext{
${ }^{1}$ Aksi terorisme ini terjadi di provinsi Jawa Timur tepatnya di Ibukota Surabaya dan daerah Sidoarjo Jawa Timur pada tanggal 13 dan 14 Mei 2018. Tiga gereja yang dibom diantaranya Gereja Pantekosta Pusat Surabaya (GPPS) milik Jemaat Sawahan, Gereja Santa Maria Tak Bercela, Gereja GKI Diponegoro, berlanjut kemudian di daerah lain masing-masing di komplek Rumah Susun Wonocolo Sidoarjo, dan aksi nekat teroris di Markas Polrestabes Surabaya. Lihat, Koran harian Pikiran Rakyat dan Republika tertanggal 15 Mei 2018.

2 Aksin Wijaya, Dari Membela Tuhan ke Membela Manusia; Kritik atas Nalar Agamaisasi Kekerasan, Bandung: PT Mizan Media Utama, 2018.hlm.1-2.

${ }^{3}$ William Montgomery Watt, Islamic Fundamentalism and Modernity terjemahan yang beredar di Indonesia berjudul Fundamentalisme Islam dan Modernitas, Jakarta: Penerbit.Raja Grafindo Persada, thn.1997). hlm.14-15.
} 
merupakan bagian dari ide agama-agama selain agama Islam; yaitu antara lain, Kristen dan Yahudi. ${ }^{4}$ Fragmentasi kemudian terjadi atas perkembangan ide dasar agama baik itu kelompok yang disebut fundamentalis-radikalis, moderat atau kelompok liberalradikal. Para cendekiawan dan intelektual Muslim mengaku tidak adanya konsepsi perkembangan yang terjadi di agama Islam secara lahiriah. Anggapan bahwa umat Islam masa Muhammad sampai detik ini tidak terlalu banyak berubah sekalipun reduksi zaman menggerogoti karakter otentik umat masa Muhammad. Kebekuan tersebut menjadi seolah-olah pembenaran akan finalitas sistem dan supremasi hukum yang menuntun perilaku insan manusia seperti yang dinyatakan dalam Al Qur'an dan al Sunnah

\section{B. Tinjauan Teori}

\section{Fundamentalisme Agama}

Pertama, ialah fundamentalisme agama yang dapat digunakan dalam studi perbandingan (comparative studies), baik sebagai konsep maupun sebagai kategori komparatif dalam satu tradisi agama maupun lintas agama. Penekanan bersandar pada kegunaan dalam mengidentifikasi "family resemblances" menggambarkan oposisi semua gerakan fundamentalisme terhadap ideologi-ideologi sekular. ${ }^{5}$ Dengan demikian, yang menjadi urgen sesungguhnya lebih kepada bagaimana istilah fundamentalisme itu digunakan sebagai basis ideologi.

Istilah fundamentalisme peneliti gunakan sebagai sebuah alat bantu analisis, bukan merupakan kategori mutlak. ${ }^{6}$ Mereka berpegang atas asa dasar agama yang kental seringkali disebut sebagai kelompok fundamentalis-radikalis. Dalam tinjauan bahasa fundamentalisme asal katanya ialah fundamental ${ }^{7}$ yang mempunyai arti yaitu asas atau hal-hal mendasar. Jika fundamentalisme ini dipahami sebagai gerakan

${ }^{4}$ Dikalangan sarjana muslim bahan-bahan yang bersumber dari tradisi Yahudi-Kristen ini biasanya dikelompokkan ke dalam kategori Israiliyyat, dan terdapat kecenderungan kuat untuk menolaknya. Lihat, Ibnu Katsir, dalam kitab Tafsir Al Qur'anul Azhim, hlm. 21.

${ }^{5}$ David Zeidan, The Resurgence of Religion: A Comparative Study of Selected Themes ini Christian and Islamic Fundamentalist, Discourses, Brill: Boston, 2003. hlm.50.

${ }^{6}$ Uraian diatas cukup mempertegas fleksibiltas kegunaan istilah fundamentalisme untuk menunjuk setiap gerakan kebangkitan dalam tradisi agama apapun yang menjadikan doktrin-doktrin agama sebagai hukum absolut.Lihat, William E.Shepard, Islam and Ideology: Toward A Typology, International Journal of Middle East Studies, vol.19, no.3 1987,hlm.307.

7 Dalam kamus bahasa Inggris John. Echols thn.2004 hlm.78; fundamentals berarti pokok, atau fundamentil, f.of Algebra (Aljabar). 
keagamaan, karakter khas fundamentalis yaitu klaim ortodoksi keagamaan bersifat doktriner yang kentara, dengan tujuan agar kembali kepada ajaran agama otentik termaktub apa adanya dalam kitab suci. Maka gagasan inti dan posisi strategis kaum beragama yang identik dengnan istilah "fundamentalisme" menuntut interpretasi lebih.

Menurut Gellner, tradisi literalis menjadi spirit yang membumi dan terejawantah oleh kaum fundamentalis. Interpretasi teks yang apa adanya, (harfiah) tidak perlu ditafsirkan dan dikompromikan. Menyebabkan tereduksinya sikap kritis dan nalar aktif dalam memahami teks. Dalam sebuah buku berjudul God and Religion in The Modern World. ${ }^{8}$ Sang penulis D.R Griffin mendaulat sistemik fundamentalisme secara ketat mendapat legal standing oleh komunitasnya dengan syarat menafsir kitab suci secara literal. Dalam realitasnya, dasar-dasar agama dalam prinsip kaum fundamentalisme, militansi yang kokoh implikasi dari terjadinya krisis. Oleh karena itu, mereka melakukan sikap defensif dengan mengacu lagi pada landasan dasar. Sebagai bentuk counter terhadap segala bentuk kebijakan dan keimanan kaum sekularis (kelompok tidak religius) yang dianggap membahayakan keberagamaan mereka. doktriner dan kembali pada praktik agama secara rasional, dengan menggunakan rasionalitas modernitas yang problematis serta pragmatis. ${ }^{9}$

Robert Garaudy menjelaskan bahwa fundamentalisme adalah fenomena melampaui persoalan agama dalam artian juga membahas hal lain diluar agama, seperti bidang politik, sosial, dan budaya. Dalam perspektif kaum fundamentalisme adalah suatu pandangan yang dikonstruksi secara mendasar kaitannya dengan

8 D. R. Griffin, God and Religion in The Postmodern World, SUNY series: Construction Postmodern, US: 1988.hlm.78

9 Lihat, Karen Amstrong dalam, "The Battle for God: Fundamentalisem in Judaism Christianity and Islam, (London: Harper Collins Publisher,2000). Menurut Amstrong saat agama merespons modernitas. Maka terbitlah Fundamentalisme di Timur (Islam) dan Barat yang memiliki makna yang sama dan sedikit perbedaan. Fundamentalis Prostestan di Amerika Serikat melakukan pengembangan ideologi yang populer dengan "sains penciptaan", menunjukan bahwa mythos dari dalam Alkitab sebenarnya ilmiah. Bentuk penolakan mereka yaitu menolak pembelajaran evolusi pada lembaga-lembaga pendidikan karena ada beberapa prinsip yang berbenturan dengan Kitab Kejadian. Upaya rasionalisasi keimanan dengan landasan ilmiah, mendekonstruksi mitos dan menegakan logos, mereka yaitu Fundamentalis Kristen melakukan pendekatan kitab dengan cara literal atau skriptualis. Fundamentalisme terbagi pada beberapa kategori yang tertuang dalam kitab Suci contoh; dalam perjanjian Lama dalam ranah konstitusional pendirian negara Israel, yang tertulis jelas dalam nomenklatur tersebut The Establishment of Jewish State (pendirian Negara Yahudi), selain itu ada tentang doktrin teologi bangsa Israel yang cukup masyhur, the promised land (tanah yang dijanjikan) dan the chosen people (bangsa pilihan, para fundamentalisme Kristen menafsirkan kitab dengan cara literal atau skriptualis dengan pola yang sama. 
keyakinan, dalam praktik keagamaan-politik, bagaimana pemahaman itu utuh dan menjadi fokus strategis. Secara utuh dan integral menjadi dasar bahwa fundamentalisme ialah gerakan yang prinsipil yang menjelajah dan mencakup pada berbagai bidang sosial, ekonomi, budaya, politik dan agama. Namun terjadi penyimpangan makna dari makna hakiki, dan kerusakan terjadi pada makna yang populer saat ini. Fundamentalisme secara dominan banyak disalahartikan dengan pertimbangan ideologi kelompok, otoritas keilmuan, dan rujukan-rujukan "penafsiran" agama yang terbatas. Berdasarkan paparan dan data di atas dapat disimpulkan bahwa: "Fundamentalisme adalah sebuah keyakinan untuk kembali pada fondasi dan dasar-dasar agama. Hal yang sama dilekatkan pula pada istilah radikalisme. Maknanya bisa positif atau --negatif. Ekses negatif yang diakibatkan dari pandangan yang fundamentalis adalah sikap kekerasan dan anarkis.”

\section{Radikalisme Agama}

Kedua, radikalisme agama secara terminologi radikalisme asal mulanya berasal dari bahasa latin yaitu; radix atau radicis, artinya akar yang disebut radicula, atau disebut radiculae; akar kecil. Pemaknaan radikalisme, merujuk kata "akar", cara berpikir mengakar. Terjadi sebuah perubahan radikal yaitu artinya perubahan mendasar, karena menyangkut dimensi paling substansial. Sebagaimana beberapa kamus yang populer yang biasa digunakan sebagai rujukan, diantaranya kamus besar Bahasa Indonesia memberikan pemaknaan 'radikal' ;menyeluruh, mengakar, dan sangat keras mengajukan perubahan. Seringpula kita mendengar, istilah Islam Radikal. Maksudnya, suatu kelompok bagian dari Islam dengan karakter khas ideologis tinggi, fanatis, dengan memperjuangkan tatanan nilai baru mendobrak tatanan nilai yang lama.

Dari beberapa analisa definisi tersebut, radikalisme dapat dipahami sebagai, "Paham keagamaan yang mengacu pada fondasi agama yang sangat mendasar, fanatik keagamaanya cukup tinggi, tidak jarang penganut paham ini menggunakan kekerasan dalam mengaktualisasikan paham keagamaan yang dianut dan diyakininya." 10

${ }^{10}$ R.Garaudy, Islam Fundametalis dan Fundamentalis Lainnya. Hlm. 90. 
ARTIKEL

Pandangan secara terminologis jika dirujuk dari Kamus Besar Indonesia ${ }^{11}$ yaitu hasil perbuatan memandang. Sedangkan menurut Bimo Walgito seorang psikolog dalam sudut pandang psikologi ${ }^{12}$ terungkap bahwa suatu pandangan dikonstruksi oleh tiga komponen: Pertama, aspek kognitif yang erat kaitannya dengan Intelektualitas; pengetahuan, pandangan, keyakinan, melibatkan tentang persepsi objek. Kedua, aspek afektif yang erat kaitannya dengan emosionalitas, kaitan dengan perasaan; rasa senang, sedih, biasa-biasa. Pada dasarnya, emosi yang keluar bisa positif (contoh: bahagia, gembira), dan juga bisa negatif (contoh:marah, takut, sedih). Ketiga, aspek konatif yaitu yang erat kaitannya dengan perilaku, suatu kecenderungan yang muncul lewat gerakan fisikal, diartikan dengan persepsi ${ }^{13}$ Persepsi bentuk pengamatan personal yang asalnya dari aspek kognisi. Persepsi dikonstruksi oleh pengalaman, dan juga wawasan.

Pada umumnya, pesantren dianggap sebagai bentuk lembaga pendidikan Islam yang religious oriented, yang mampu meletakan dasar-dasar pendidikan agama yang kuat. ${ }^{14}$ Warga Pesantren diuji untuk memberikan pengamatan entitas objek penelitian dengan objektivitas secara psikologik dengan cara padangnya sendiri buah pancaran nilai dari kepribadiannya. Ornamen objek psikologik itu diantaranya berkaitan dengan; kejadian, ide pada suatu situasi tertentu. Karena, faktor pengalaman, yaitu proses kehidupan yang membentuk konstruksi pemikiran untuk melihat struktur atas objektivikasi yang dilakukan. Sedangkan Intelektualitasnya serupa dengan seberkas cakrawala yang memberikan simpulan objek psikologik diatas. Komponen kognitif ini mengeluarkan ide, dan inspirasi kontinyu bagi konsep yang diteliti. ${ }^{15}$

Chaplin dalam kamusnya, menyatakan bahwa sikap warga pesantren ialah predisposisi dan kecenderungan stabil yang berlangsung secara konsisiten menghasilkan tingkah laku sebagai cara bereaksi inidvidu lain, objek atau lembaga

\footnotetext{
11 Kamus Besar Bahasa Indonesia Edisi Ketiga, vol. 1.thn.2002,hlm.821.

12 Bimo Walgito, Psikologi Sosial Suatu Pengantar, Yogyakarta: Fakultas Psikologi UGM,thn.1994.hlm.110

13 Mar'at, Sikap Manusia, Perubahan serta Pengukurannya, Bandung, Ghalian. thn.1981.thn. hlm.22-23.

${ }^{14}$ Anwar, Rully Khairul, Neneng Komariah, and M. Taufiq Rahman. "Pengembangan Konsep Literasi Informasi Santri: Kajian di Pesantren Arafah Cililin Bandung Barat." Wawasan: Jurnal Ilmiah Agama dan Sosial Budaya 2.1 (2017): 131.

${ }^{15}$ Rifai \& Chatarina Tri Anni, Psikologi Pendidikan, Semarang: UNNES, thn.2009. hlm.89.
} 
(dalam hal ini pesantren) atau persoalan tertentu. ${ }^{16}$ Menurut M. Ngalim Purwanto, Sikap merupakan cara bereaksi pada suatu rangsangan, suatu kecenderungan untuk bereaksi dengan cara tertentu terhadap suatu rangsangan atau fenomena yang terjadi ${ }^{17}$

Sikap ialah kecenderungan stabil yang menetap terkadang relatif beraksi dengan baik atau buruk terhadap individu atau suatu barang. ${ }^{19}$ Sikap ialah pra aksi dalam suatu perbuatan dengan arahan tertentu. Sikap pada dasarnya terbagi pada dua macam yaitu individual dan sosial. Sikap ialah sebuah kecenderungan yang muncul atas keadaan, terakumulasi menjadi kekuatan jiwa seseorang atas dorongan bertingkah laku pada objek khusus dengan teknis tertentu, baik objek positif ataupun negatif ${ }^{18}$

Warga pesantren pada penelitian ini ialah elemen-elemen individu yang berkumpul dalam satu lingkungan yang sama. Memiliki tingkatan hirarkis dan pengaruh, serta memiliki pandangan dan sikap yang khas masing-masing, terdiri dari: Kyai, Santri, dan Pengurus.

\section{Metode Penelitian}

Penelitian ini menarik untuk dilakukan atas dasar pertimbangan: Pertama, tren pesantren Tahfizhul Qur'an yang berkembang di era milenial. Metode hafalan Al Qur'an ialah pembasisan teks Al Qur'an secara oral yang seringkali tidak memerlukan interpretasi/penafsiran. Dengan beberapa kemungkinan, terjadi pandangan dan sikap khas fundamentalisme-radikalisme agama yaitu tekstualis/skriptualis.

Kedua, berdasarkan tujuan yang telah diuraikan sebelumnya, pada penelitian ini penulis akan rnengungkapkan bagaimana Pesantren Tahfizhul Qur'an membuat sebuah kontruksi sikap dan pandangan keagamaan terhadap warga Pesantren tentang fenomena Fundamentalisme-Radikalisme. Sebagai sebuah realitas dan fenomena social; fundamentalis dan radikalisme menjadi wujud bahwa sebuah agama

\footnotetext{
${ }^{16}$ J.P.Chaplin, Kamus Lengkap Psikologi, (Jakarta: PT Raja Grafindo Persada, 1995),hlm.43.

17 M.Ngalim Purwanto, Psikologi Pendidikan, (Bandung: PT. Remaja Rosda Karya,1990), hlm. 141.

18 Muhibbin Syah, Psikologi Pendidikan, (Bandung:PT Remaja Rosdakarya, 2011), hlm.118.
} 
mengalami perkembangan organik yang hidup di zamannya, dalam merespon isu modernitas dan sekularitas.

Tujuan penelitian ini, berupaya memberikan pemahaman yang benar dan mengakar pada nilai-nilai ajaran pondok pesantren, yang sebagian kalangan masyarakat sering menamakan fenomena fundamentalisme-radikalisme ini dengan "'Islam fundamentalis", "radikalis", "ekstrimis", "sarang teroris".

Pada penelitian ini pula penulis sangat berhati-hati dalam memilah, menganalisa, serta tidak mudah mengeneralisir masalah yang berkembang terhadap klaim-klaim yang terkait dengan umat Islam secara keseluruhan, terlebih kepada kelompok Islam yang memiliki lembaga pendidikan dan sejumlah alumninya di berbagai tempat.

Penulis juga bermaksud memberikan pandangan kepada masyarakat bahwa pemahaman Islam sepanjang sejarah Indonesia tidak terlepas dari nilai-nilai pesantren dan perjuangan para santri. Serta memberikan pemahaman bahwa pola pendidikan pesantren berkontribusi besar membangun visi dan misi untuk membangun bangsa ini.

Fundamentalisme di definisikan sebagai Spirit pemahaman keagamaan yang cenderung literal non kontekstual menolak sekulerisasi dan modernisasi Barat. ${ }^{19}$ Ketiga, terminologi Radikalisme didefinisikan sebagai pemahaman keagamaan yang mendasar cenderung pro terhadap aksi kekerasan sebagai bentuk aktualisasi nilai keagamaannya. ${ }^{20}$ Adapun indikator-indikatornya antara lain, berlandaskan turunan teori Fundamentalisme Agama, dalam hal ini mengambil konstruksi dari Fundamentalisme Kristen James Barr ${ }^{21}$, kemudian indikatornya diambil dari tematema fundamentalisme-radikalisme Islam khas Indonesia. Diantaranya:

1. Khilafah (Negara Islam), Jihad, Bom Bunuh Diri, Hukum Pidana Islam; Qishosh, Rajam, Potong Tangan, dsb. Pandangan terhadap Sekulerisme, Liberalisme, Demokrasi, negara AS dan pengaruhnya di dunia dsb.

\footnotetext{
19 A. Azra, Pergolakan Politik Islam; dari Fundamentalisme..hlm.76.

20 R.Garaudy, Islam Fundametalis dan Fundamentalis Lainnya, Pustaka,Bandung: 2002.hlm.89.

${ }^{21}$ James Barr, Fundamentalisme,London: SCM Press di terbitkan ulang oleh PT.BPK Gunung Mulia, Jakarta,thn. 2011).hlm.66.
} 
2. Sikap Toleransi atas Perbedaan

Dimensi praktik agama maupun sosial responden tentang tingkat Toleransi juga perasaan keagamaan dan pengalaman spiritual berkaitan dengan toleransi agama.

3. Sikap terhadap Penafsiran Kontekstual Dimensi pengalaman responden dalam menyikapi tafsir Kontekstual dan interpretasi terhadap ayat-ayat $\mathrm{Al}$ Qur'an.

4. Nilai Tasawuf dalam keseharian; Sikap Tawassuth dan Zuhud

Dimensi konsekuensional meliputi persepsi responden tentang praktik, pengalaman tasawuf yang terekspresikan dalam perilaku kehidupan sehari-hari diantaranya tawasuth dan zuhud.

Keempat, variabel yang harus di definisikan yaitu Pandangan, pandangan didefinisikan juga sebagai persepsi. ${ }^{22}$ Persepsi merupakan proses pengamatan seseorang yang berasal dari komponen kognisi. Persepsi ini dipengaruhi oleh faktor-faktor pengalaman, cakrawala akal dan dominasi pengetahuannya. Dimana, seorang manusia mengamati suatu objek psikologik dengan kacamatanya sendiri dengan diwarnai oleh nilai dari kepribadiannya.

Kelima, yaitu variabel untuk mengukur dan mengambil sampling data yaitu berkaitan dengan variabel sikap. Sikap di definisikan sebagai suatu cara bereaksi terhadap suatu perangsang, suatu kecenderungan untuk bereaksi dengan cara tertentu terhadap suatu pandangan atas situasi yang terjadi ${ }^{23}$

Jenis penelitian ini adalah kualitatif lapangan, dengan pendekatan emik ${ }^{24}$ yaitu analisis sikap dan perilaku yang menekankan pada apa yang disampaikan, dipikirkan dan dipersepsikan oleh informan tentang materi penelitian yaitu terkait pandangan dan sikap warga pesantren terhadap fenomena fundamentalismeradikalisme agama.

22 Mar'at, Sik.ap Manusia, Perubahan serta Pengukurannya ,hlm.22-23.

${ }^{23}$ Ngalim Purwanto,Psikologi Pendidikan,(Bandung:PT.Remaja Rosda Karya,1990), hlm.141.

24 Pendekatan emik yaitu pendekatan yang berusaha memahami perilaku individu atau masyarakat dari sudut pandang si pelaku sendiri. Studi emik bersifat lebih privat tidak dapat digeneralisasikan secara luas. Pendekatan ini mencakup upaya untuk mengkomunikasikan keadaan internal (inner psychological states) dan perasaan individu yang berkaitan aktivitas perilaku. Lihat, Pertti J.Pelto, Anthropological Research: The Structure of Inquiry, Harper \& Row Social Science, New York and London,thn.1970.hlm. 65. 
Jenis penelitian ini adalah kualitatif lapangan, dengan pendekatan emik ${ }^{25}$ yaitu analisis sikap dan perilaku yang menekankan pada apa yang disampaikan, dipikirkan dan dipersepsikan oleh informan tentang materi penelitian yaitu terkait pandangan dan sikap warga pesantren terhadap fenomena fundamentalismeradikalisme agama.

\section{Hasil dan Pembahasan}

\section{Pesantren Tahfizhul Qur'an Hidayatullah Bandung}

Hidayatullah merupakan salah satu ormas Islam yang fokus bergerak di da'wah dan tarbiyyah. Selain bergerak di bidang tersebut, Hidayatullah menyebarkan paham keagamaannya melalui media dan dunia jurnalistik. ${ }^{26}$ Pemahaman keagamaan yang khas fundamentalis diduga menjadi alasan bagi Kominfo untuk memblokir situs Hidayatullah.com bersama 19 situs lain ${ }^{27}$. Lalu, kemudian terjadi pencabutan kembali setelah ada klarifikasi dan temuan baru di lapangan. Isu tentang ormas Islam Fundamentalis-Radikalis sebelumnya terjadi juga pada kepemimpinan presiden SBY, Hidayatullah kembali dituduh sebagai ormas yang memiliki faham FundamentalisRadikalis setelah keterlibatan guru di Pesantren Hidayatullah yang ikut jaringan teroris Solo.

\footnotetext{
25 Pendekatan emik yaitu pendekatan yang berusaha memahami perilaku individu atau masyarakat dari sudut pandang si pelaku sendiri. Studi emik bersifat lebih privat tidak dapat digeneralisasikan secara luas. Pendekatan ini mencakup upaya untuk mengkomunikasikan keadaan internal (inner psychological states) dan perasaan individu yang berkaitan aktivitas perilaku. Lihat, Pertti J.Pelto, Anthropological Research: The Structure of Inquiry, Harper \& Row Social Science, New York and London,thn.1970.hlm. 65.

26 Terkait media dan jurnalistik di Hidayatullah ada dalam sebuah naungan LMH (Lembaga Media Hidayatullah). Lembaga ini merupakan sarana dakwah Hidayatullah lewat tulisan. Ada beberapa produk media massa yang diterbitkan oleh Kelompok Media Hidayatullah, yaitu majalah bulanan Suara Hidayatullah yang kini beroplah 55 ribu eksemplar, situs berita Hidayatullah.com, majalah Edisi Khusus Hidayatullah yang terbit empat bulan sekali, dan buletin al-Qolam. Lembaga ini memiliki pula devisi percetakan (Lentera Jaya Madina), penerbitan (Lentera Optima Pustaka), dan konsultan media (Lentera Prima Media).

${ }^{27}$ Berdasarkan rilis resmi www.kominfo.go.id, dengan judul "BNPT minta Kominfo Blokir 22 Situs Radikal". Ada 22 situs internet radikal yang diadukan oleh Badan Nasional Penanggulangan Terorisme (BNPT), kata Ismail, di Jakarta, Senin (30/3). Menurutnya, awalnya pihak kepolisian telah memblokir 3 (tiga) situs, namun BNPT melaporkan kembali untuk memblokir 19 situs berdasarkan surat bernomor no.149/K.BNPT/3/2015 tentang situs/website Radikal ke dalam system filtering Kominfo. Situs resmi ormas Hidayatullah yaitu Hidayatullah.com masuk ke dalam list tersebut di nomor ke.10 dari 22 situs. Namun hari ini, situs Hidayatullah.com kembali bisa diakses berkat konfirmasi dan pembuktian konten situs tidak mengandung unsur-unsur radikalisme, sebagaimana paparan KH.Endang Lc pimpinan pondok Pesantren Tahfizhul Qur'an Hidayatullah ketika peneliti wawancarai.(red.18/07/2018).
} 
Hidayatullah secara filosofi gerakan mereka di landasi dengan metode yang mereka sebut dengan manhaj kenabian atau dikenal dengan manhaj nubuwwah. Pola organisasi khas fundamentalis yaitu berpegang pada al Qur'an dan as-Sunnah sebagai bentuk ketaatan kepada Allah dan Rasul Nya. ${ }^{28}$

Hidayatullah memiliki fokus pada tugas-tugas keumatan seperti; meluruskan aqidah umat, mengorganisir umat lewat imamah, dan juga melakukan pembaharuan pada jama'ah atau sering disebut dengan tajdid, pencerahan kesadaran dan pembersiha jiwa yang sering disebut dengan istilah Tazkiyyatu An Nufus dan pendidikan berkelanjutan yang disebut dengan ta'limatul Kitab wal Hikmah.

Tentunya, dengan tujuan akhir melahirkan kepemimpinan bagi ummat. Pada permulaan perkembangannya, Hidayatullah memiliki distribusi anggota dengan pola kaderisasi melalui jalur pendidikan. Maka Hidayatullah ikut berperan dalam menyemaikan dan membumikan ajaran-ajaran agama melalui proses panjang dan berkelanjutan. Penelitian ini mencoba menggali bagaimana Hidayatullah melakukan pembasisan ideologi keagamaan lewat pendidikan. Selain itu Hidayatullah, membingkai pesantren dengan konsepsi dan metodologi pendidikan integral berbasis Tauhid. Membangun serta membuka pasar-pasar syari'ah dan ekonomi keumatan yang berdaya saing dan berdaya jual. Selain itu, memiliki program sinergis berupa pemberdayaan kaum dhuafa dan mustad'afhin. Secara khas ingin membangun lingkungan kampus yang alami, ilmiah dan Islamiah. Pesantren Hidayatullah mempunyai fungsi sebagai: Lembaga pendidikan peragaan syari’at Islam.

Lembaga pendidikan dakwah dan rekrutmen anggota. Lembaga pendidikan dan juga sekaligus lembaga pengkaderan. Diluar itu, memberdayakan ekonomi- dan bakti sosial. Membangun wilayah pemukiman muslim sebagai miniatur peradaban Secara intensf melakukan pembinaan dan perkaderan demi lahirnya pemimpin dan para pejuang peradaban Islam. Upaya riilnya yaitu mendirikan lembaga/usaha ekonomi produktif untuk pendanaan jama'ah dan perjuangan peradaban Islam. Memberdayakan dhu'afa dan mustadh'afin menuju kehidupan mandiri dan kompetitif.

\footnotetext{
${ }^{28}$ Spirit yang sama dimiliki juga oleh ormas-ormas lain, seperti: Muhammadiyyah dan PERSIS (Persatuan Islam) yang telah jauh lebih dahulu berdiri. Rahman, M. Taufiq, and Beni Ahmad Saebani. "Membangun gerakan inklusivisme model jamaah Persatuan Islam." TEMALI: Jurnal Pembangunan Sosial 1.1 (2018): 58-72.
} 
ARTIKEL

\begin{abstract}
Daarul Qur'an Internasional (SDQI) merupakan sebuah lembaga pengelola sedekah yang berkhidmat pada pembangunan masyarakat berbasis tahfizhul Qur'an yang dikelola secara profesional dan akuntabel. Program Daarul Qur'an Internasional (SDQI) ini disingkat PPPA (Program Pembibitan Penghafal Al Qur'an).
\end{abstract}

Pada tahun 2003, saat Ustadz Yusuf Mansur berinisiatif untuk menciptakan kader-kader penghafal Al-Qur'an di Indonesia. Awalnya, mengasuh beberapa santri tahfizh, kemudian berkembang hingga ribuan santri yang tersebar di berbagai daerah. Paham keagamaan yang digagas Daarul Qur'an Internasional (SDQI) ialah back to the sacred dalam hal ini Al-Qur'an sebagai sumber inspirasi manusia dalam kehidupan. PPPA Daarul Qur'an Internasional (SDQI) yang awalnya berkonsentrasi dalam upaya membangun kesadaran masyarakat untuk kembali pada Al-Qur'an. PPPA Daarul Qur'an Internasional (SDQI) membangun gerakan Rumah Tahfizh di dalam dan luar negeri. Melalui program dakwah dan sosial, PPPA juga terlibat dalam pembangunan kemandirian dan pengembangan masyarakat berbasis tahfizhul Qur'an. Mengakomodir semua dari mulai bantuan beasiswa, kemanusiaan, kesehatan, dan pengembangan SDM. Berbagai program yang sangat menunjang kreatif, membumi, dan tepat sasaran PPPA terus dipercaya masyarakat sebagai mitra program filantropi karena memberdayakan pembangunan bangsa berbasis tahfizhul Qur'an.

Lantas kemudian berkembang dengan masuk ke ranah pendidikan dengan berdirinya Pesantren Tahfizh Daarul Qur'an Internasional (SDQI) adalah pesantren yang mengharmonikan Tahfizh Al-Qur'an dirosah islamiyah, pendidikan formal, life skill, aktifitas social dan dakwah. Melalui pembelajaran khas Daarul Qur'an Internasional (SDQI) yaitu DAQU Method yang ingin menjadikan santri sebagai penghafal Al-Qur'an yang berkarakter dengan menjadikan ibadah wajib dan sunnah Rasulullah SAW sebagai pakaian harian. Pembangunan Pesantren Tahfizh Daarul Qur'an Internasional (SDQI) di sejumlah daerah seperti;Tangerang, Cikarang, Semarang, Bandung, Lampung, Jambi, Banyuwangi, Cilegon dan Malang, dengan ribuan santri penghafal Qur'an.

Pandangan kedua warga pesantren Pandangan tentang Konsep Khilafah."Khilafah secara terminologis yaitu fase selanjutnya pasca kepemimpinan Nabi”. Salah satu nash shahih berkaitan dengan Khilafah itu ada haditsnya atau 
sumber yang menunjukan ${ }^{29}$. Dalam teks tersebut dinyatakan akan ada suatu saat nanti khilafah atau pemerintahan dengan manhaj kenabian. Berbicara kapan itu akan terjadi, tergantung bagaimana ikhtiar kita untuk mewujudkannya. Dalam paham keagamaan Hidayatullah Khilafah itu merupakan bentuk sinonim dari "Peradaban Islam ".Islam telah sempurna dengan diutusnya Nabi Muhammad beserta perangkat-perangkat agama secara tuntas. Analoginya, tidur ada doanya masuk wc ada doa. Apalagi berkaitan dengan hal fundamental yaitu sistem ke tata negara-an. Hakikatnya, Ke Khilafahan merupakan bentuk manifestasi dari keimanan, aturan-aturan dalam $\mathrm{Al}$ Qur-an dan As Sunnah. Banyak hukum-hukum dalam Al Qur'an; pajak,waris, hukum pidana, hukum keluarga, dan sampai etika. Sesungguhnya bahwa khilafah wajib ditegakkan adalah hal yang mesti kita yakini (Imani/fides). ${ }^{30}$ Adapun konsekuensi yuridis apakah Khilafah ini wajib ditegakkan di Indonesia, masuk dalam ranah khilafiah (debatable). Dalam terjemahan Hidayatullah upaya untuk mewujudkan peradaban Islam yaitu salah satunya dengan berkonsentrasi dalam dunia pendidikan sejak pendidikan dini RA-PAUD sampai perguruan tinggi. Kita ingin membuat miniature peradaban Islam. Miniaturnya ialah pesantren. Manifestasi keimanan dalam setiap jejak kehidupan. Ada 300 pesantren, terkoordinasi terkomandoi oleh pusat. ${ }^{31}$

Warga Pesantren Daarul Qur'an memiliki pandangan bahwa urusan politik diatur oleh agama. Agama tidak bisa digunakan sebagai alat jual untuk memperjuangkan kekuasaan politik (yang menghalalkan berbagai cara). Karena ketika politik itu menciderai nilai dan etika moral (contoh: korupsi), maka agama yang akan ternodai bukan subjeknya. Pandangan terhadap Amerika Serikat atau Barat atas hegemoni dan dominasinya selama ini, kedua warga pesantren memandang bahwa tidak perlu adanya penolakan atas produk mereka jika tidak ada unsur penjajahan atau mendzholimi umat Islam. Seharusnya jika hendak memegang prinsip mandiri terlepas dari penjajahan, kita wajib mencintai dan mendukung produk dalam negeri. Pesantren Hidayatullah memandang demokrasi sebagai pola atau cara memilih pemimpin. Karena secara substansional yang wajib itu adalah memilih atau menentukan

29 Sebuah hadits riwayat Imam Ahmad, dengan redaski "Satakunu Khilaafataan ala minhaaji Nubuwwab"

30 Wawancara dengan ketua yayasan (pengurus pesantren) al Ustadz Wahid, di di kantor atau ruang pertemuan, pada tanggal 21 Juni 2018 pukul 10.00-12.00.

31 Berdasarkan keterangan dari Kyai Endang Abdurrahman, S.Ag. (Pimpinan Pesantren Tahfizhul Qur'an Hidayatullah Bandung) pada tanggal 21 Juni 2018 pukul 10.00-12.00 di kantornya. 
kepemimpinan bukan model atau cara memilihnya. Maka demokrasi dirasa tepat sebagai ijtihad untuk merumuskan dan melegalkan mekanisme pemilihan.

Warga pesantren Daarul Qur'an memiliki pandangan bahwa khilafah itu sudah habis pasca Khalifah Turki Utsmaniyyah. Tidak ada cara mewujudkan khilafah, apalagi dengan cara paksaan yang merubah ideologi dan konsep Islam itu sendiri. Daarul Qur'an memandang bahwa Islam mewujudkan nilai-nilai universalitas yang melindungi hak manusia dan semesta yaitu Islam Rahmatan Lil Alaamin.

Sedangkan, Pesantren Hidayatullah memandang bahwa ke-khilafahan akan terjadi (berdasarkan petunjuk teks Al Qur'an dan Al Hadits), namun pemaknaan "Khilafah" lantas dikonversi pada makna "Peradaban Islam". 32

Kedua warga pesantren memandang bahwa sikap toleransi merupakan hal yang urgen. Contohnya, dalam sudut pandang warga Pesantren Daarul Qur'an bahwa secara mutlak Al Qur'an melarang bagi seorang muslim memaksa orang untuk masuk agama Islam, apalagi diluar itu ketika memaksakan keyakinan dengan cara kekerasan. Sedangkan, Pesantren Hidayatullah dalam bersikap terhadap non Muslim memandang bahwa negara kafir itu merupakan Daaru Da'wah (negara yang mesti didakwahi) bentuknya dengan melakukan dakwah dalam berbagai bidang dengan prinsip muamalah (perdagangan, pendidikan, kerjasama lintas negara dan lain-lain), sepanjang tidak berbenturan dengan hal prinsipil yaitu aqidah. Dan kedua warga pesantren, sepakat jika dalam suatu waktu terjadi konflik dan peperangan, umat Islam wajib melawan ketika diserang.

Lalu berkaitan, dengan ayat-ayat hukum terkait Hukum pidana Islam, jihad, dan hukum tata negara, kedua warga pesantren sepakat bahwa disana terdapat ruang interpretasi dan ijtihad terbuka. Tidak bisa dimaknai tekstual, diluar itu kedua pesantren memakai kurikulum secara integral (memadukan umum dan agama) serta mengikuti alur formal yang diatur oleh Kemenag ataupun Kemendikbud serta kedua warga pesantren memakai kitab-kitab penunjang sebagai media pembelajaran tidak mutlak menghafal Al Qur'an secara oral.

\footnotetext{
32 Hasil wawancara dengan al Ustadz Wahid. 


\section{Relasi Pandangan dan Sikap Warga Pesantren}

Pandangan dan sikap warga pesantren dibentuk oleh karakter pesantren itu sendiri, yaitu: 1) Tawassuth yang berarti tidak memihak atau moderasi. 2) Tawazun, menjaga keseimbangan dan harmoni. 3) Tasamub, toleransi. 4) Tasyawur, musyawarah. 5) Adil, bersikap adil dalam beraksi ataupun bereaksi. Kelima karakter inilah yang membentuk santri dalam menjalani kehidupan riil di masyarakat. Dengan lima karakter seperti disebutkan di atas, pesantren sebagai institusi pendidikan yang mengajarkan kearifan, sangat berperan dalam meluruskan pemahaman tentang ajaran Islam yang dapat mendekonstruksi makna dan hakikatnya. Seperti halnya, istilahistilah yang berkembang, misalnya dalam konteks ini adalah tentang jihad dan radikalisme. Para kyai mengajar santri di pesantren dengan berbagai kitab mulai dari aqidah, akhlak, fiqh, tafsir, hadits, sejarah, dan lain sebagainya. Istilah jihad, mati syahid, musuh Islam, kafir dan lain-lain bukanlah istilah yang asing bagi warga pesantren. Misalkan dalam mengamalkan term jihad dalam "arti berperang", tentu para kyai yang paling pertama melakukannya karena mereka relatif mendalam pengetahuan agamanya, termasuk dalil-dalil berjihad.

Warga Pesantren Tahfizhul Qur'an Hidayatullah maupun warga pesantren Tahfizhul Qur'an Daarul Qur'an merupakan warga pesantren yang dalam kesehariannya agar menjawab kebutuhan legislasi hukum dan penegakan keadilan di suatu tatanan kehidupan yang kompleks. Hukum Syariat mengalami beberapa perkembangan yaitu Pertama, fase Syar'iat; dimana sumber utama Al Qur'an dan Al Sunnah tidak di rincikan dan beredar secara acak. Kedua, fase Fiqh; dimana sumber Al Qur'an dan Al Sunnah itu mulai dipilih berdasarkan tema- tema spesifik, dan dipahami ulama dengan catatan dan penjelasan lebih utuh. Ketiga, fase Taqnin; dimana setiap penjelasan dalil diuraikan dan dilegal standing kan pada kitab-kitab undang, dalam konteks Indonesia contohnya: HKI (Hukum Kompilasi Islam) ${ }^{33}$ Ayat Abkam

${ }_{33}$ Pada dasarnya ayat-ayat hukum hanya memberikan penjelasan bahwa perkara hukum muamalah dan hukum pidana memberikan pedoman hukum secara general, agar para sarjana Islam dan para "penguasa" dapat merumuskan dan melakukan tata kelola undang-undang yang dijiwai spirit kontekstual. Dengan syarat pengaturan tidak berdiametral dengan spirit Al-Qur'an dan hukum Islam itu sendiri. Hukum Akhwal Syahsiyyah (hukum keluarga) diantaranya persoalan perkawinan dan soal warisan diuraikan secara rinci dan jelas tertuang dalam Al-Qur'an. Jumlahnya ketika dihitung cukup (sekitar 70 ayat) jika dikomparasikan hukum-hukum pada beberapa tema lain, diantaranya hukum pemerintahan dan Tata Negara berjumlah 10 ayat dan hukum Internasional berjumlah 25 ayat. Mengenai beberapa kelompok ayat-ayat hukum yang disebut terakhir ini, yaitu hukum perdata 
mengenai bidang lain seperti sosial-ekonomi tidak begitu terekspos dan tergali, karena pada dasarnya persoalan kelas sosial; Individu, masyarakat, menjadi pra syarat bagi terwujudnya masyarakat yang tidak hanya memiliki moral bagus tapi juga maju. Anggota individu di tengah-tengah masyarakat menilai bahwa tidak ada relasi antara ayat Ahkam dengan perdagangan dan sisi lainnya yaitu bidang ekonomi.

Dalam kajian ekonomi diantaranya persoalan perniagaan; jual beli, perdagangan belum diselesaikan dalam konteks faktual dan pembacaan realitas sebenarnya, sebagian ayat hanya berbicara dalam pendampingan dan pelayanan masyarakat lemah. Secara fungsional ayat-ayat ahkam tidak "hidup" untuk menjawab persoalan ini. Berdasarkan penjelasan tersebut, ayat-ayat hukum masih sebagian yang secara "langsung" menangani hajat hidup kemasyarakatanberinteraksi dengan ayatayat Al Qur'an. bahwa ayat Al-Qur'an secara keseluruhan. Konteks antara hukum dan warga Pesantren ialah adanya pesantren yang mengikat dan mengatur penghuninya (dalam hal ini warga pesantren). Pertanda, bahwa "hukum" seringkali dibuat untuk dilanggar terutama bagi mereka yang sengaja menciptakannya. Adanya hukum yang sejalan dengan pesantren yaitu hukum yang mengkonstruksi masyarakat (kumpulan) menjadi orang yang memiliki keimanan (fides), dalam satu pesantren dengan ragam budaya dari daerah masing-masing. Hukum Islam yang secara general tidak diatur seluruhnya dari ajaran-ajaran Rasul, dengan konsekuensi ayat-ayat tersebut.

\section{Analisis Sikap Warga Pesantren}

Faktor pemicu terjadinya aksi radikalisme terjadi bukan karena sebab tunggal. Ada banyak faktor yang dominan berpengaruh; perubahan sosial, kondisi ekonomi, kondisi lingkungan, pola pendidikan, sampai iklim politik berpengaruh besar dalam menciptakan fundamentalisme-radikalisme Islam. Menurut kedua warga pesantren, merupakan hal paradoks fundamentalisme- radikalisme berasal atau hasil dari pendidikan pesantren.

Dan hal tersebut, mengakar sejak masa lampau dimana terjadi dinamika antara agama dan pemeluk agamanya sendiri. Dalam hal ini, pesantren dan warga

berjumlah 70 ayat, hukum pidana berjumlah 30 ayat, hukum ekonomi keuangan berjumlah 10 ayat, dan hukum acara berjumlah 13 ayat, beserta perangkatnyaAl Qurthubi, Tafsir Ahkam, Beirut: Dar El Kotob, 2000,hlm.28. 
pesantren, tujuan pesantren yang menjadi acuan dalam penelitian ini adalah mendidik dan melahirkan kader yang menjadi ahli agama dan cendekiawan ulama (tafaqquh fi al-din) selain itu menguasai IPTEK dan tidak anti modernisasi pendidikan. Karena itu, warga pesantren baik itu Daarul Qur'an maupun Hidayatullah menawarkan ajaran Islam yang khas Indonesia; menghargai perbedaan, selain sebagaimana tugas utamanya mempelajari pemahaman agama Islam ; ilmu tauhid, fiqih dan syariah, dan akhlaq atau norma Islam. Menampilkan ciri khas pesantren memasyarakatkan islam, dan mengislamkan masyarakat.

Secara historis, di berbagai pulau di Indonesia sampai ke pelosok-pelosok kampung; baik itu di Jawa, Sumatera, serta Kalimantan, terjadi dialog dengan kebudayaan masyarakat di sekitarnya. Pesantren-pesantren di Jawa Timur, diantaranya penganut mazhab Syafi'i, menunjukan dan menampilkan sikap akomodatif yang dinamis dengan khas budaya sekitar sehingga warga pesantren melakukan pembauran dengan masyarakat secara natural. Pola dialog dan keterbukaan warga pesantren menjadi ujung tombak keberhasilan pesantren menjadi model pendidikan percontohan keberagamaan yang toleran.

Demokratisasi dalam ruang kebebasan beragama ialah upaya bagaimana seharusnya toleransi agama bisa dibangun di tengah keragaman komunitas umat beragama. Bahkan dalam tafsir Al Azhar Hamka menegaskan toleransi agama tidak hanya menyangkut bidang muamalah antar pemeluk agama, namun juga menyangkut segi keimanan (teologis). Di bidang keimanan, Hamka memberikan ruang kebebasan beragama, mengakui adanya jalan-jalan keselamatan bagi kaum beriman dan memberi tempat khusus bagi golongan Ahli Kitab. Sedang di bidang muamalah, Hamka menganjurkan suatu kehidupan harmoni penuh kedamaian antar umat beragama, membolehkan pernikahan antara seorang pria Muslim dengan wanita yang baik dari golongan Ahli Kitab, dan mengharuskan umat Islam untuk ikut memelihara dan melindungi rumah-rumah suci dan tempat peribadahan agama lain dari tindakan desktruktif. ${ }^{34}$

${ }^{34}$ Hamka, Tafsir Al Az̧har,QS.Al Kaafirun satu s.d akhir, Jakarta: Pustaka Kalam.edisi baru 2013. 


\section{Nilai-Nilai Keberagamaan dan Keislaman Moderat}

Kedua warga pesantren mengusung paradigma moderat, dan cenderung mencoba mengintegrasikan pandangan-pandangan yang antagonistik dalam melihat hubungan Islam dan persoalan kemasyarakatan, sekaligus ingin melunakkan Paradigma Konservatif yang seringkali melakukan generalisasi bahwa Islam selalu mempunyai kaitan atau hubungan yang tak terpisahkan dengan masalah-masalah kemasyarakatan serta berusaha mengakomodasi dilakukannya pembaruan wacana sesuai dengan diinginkan kalangan liberal dengan tetap memperhatikan nilai-nilai luhur dan keislaman.

Sesuai dengan konsep Islam sebagai agama wasathan (moderat), maka dalam melihat hubungan Islam dan negara, paradigma moderat menolak pendapat bahwa Islam adalah agama yang serba lengkap dan bahwa dalam Islam terdapat sistem ketatanegaraan. Tetapi kelompok ini juga menolak anggapan bahwa agama adalah dalam pengertian barat yang hanya mengatur hubungan manusia dengan Tuhan. Paradigma ini juga berpendirian bahwa dalam Islam tidak terdapat sistem ketatanegaraan tetapi terdapat seperangkat tata nilai etika bagi kehidupan bernegara. Pesantren yang berpegang pada paradigma ini tidak hanya ingin menonjolkan isu seputar konsep "Negara Islam" dan "Pemberlakuan syariat", tetapi yang paling penting bagaimana substansi dari nilai dan ajaran agama itu sendiri. Agama adalah sejumlah ajaran moral dan etika sosial, selain itu agama juga berfungsi sebagai alat kontrol negara. Paradigma moderat berpandangan, keterlibatan agama secara praktis ke dalam negara jangan sampai memandulkan nilai luhur yang terkandung dalam agama karena agama akan menjadi ajang politisasi dan kontestasi.

\section{E. Kesimpulan}

Pesantren yang bersikap moderat tidak pernah menggunakan kitab-kitab sebagai rujukan kecuali kitab-kitab muktabar dan khas Indonesia seperti karya ulama-ulama Nusantara; An Nawawi, Al Makassari, dan lain-lain. Simbol dari pesantren yaitu para kyai sebagai pemimpin pesantren bersikap lapang dalam menerima perubahan bagi penyelenggaraan pembelajaran di pesantrennya, meskipun mereka juga tetap menjaga ciri khas dari sistem pendidikan Islam 
ARTIKEL

tradisional ini. Mereka yakin bahwa perubahan harus dilakukan sikap responsif terhadap tuntutan zaman tanpa merusak aspek-aspek positif dari kehidupan masyarakat. Keterbukaan tersebut dalam kenyataannya bahkan telah semakin memperkuat eksistensi lembaga pendidikan pesantren. Para kyai dari kedua pesantren, memegang kendali memimpin pesantren bersikap lapang dalam menerima perubahan bagi penyelenggaraan pembelajaran di pesantrennya, meskipun mereka juga tetap menjaga ciri khas dari sistem pendidikan Islam tradisional ini. Mereka yakin bahwa perubahan harus dilakukan sebagai respon terhadap tuntutan zaman tanpa merusak aspek-aspek positif dari kehidupan masyarakat. Keterbukaan tersebut dalam kenyataannya bahkan telah semakin memperkuat keberadaan lembaga pendidikan pesantren ini.

Kedua warga pesantren mengusung paradigma moderat, dan cenderung mencoba mengintegrasikan pandangan-pandangan yang antagonistik dalam melihat hubungan Islam dan persoalan kemasyarakatan, sekaligus ingin melunakkan Paradigma Konservatif yang seringkali melakukan generalisasi bahwa Islam selalu mempunyai kaitan atau hubungan yang tak terpisahkan dengan masalah-masalah kemasyarakatan serta berusaha mengakomodasi dilakukannya pembaruan wacana sesuai dengan diinginkan kalangan liberal dengan tetap memperhatikan nilai-nilai luhur dan keislaman.

Perubahan dalam masyarakat bisa dipicu oleh beberapa factor penyebab, antara lain: ilmu pengetahuan atau pendidikan, kemajuan teknologi serta penggunaannya oleh masyarakat, agama, dan perubahan harapan dan tuntutan manusia itu sendiri, wujud perubahan sosial itu bisa berupa kemajuan (progress) ataupun kemunduran (regress).

\section{DAFTAR PUSTAKA}

Al Qurthubi, Tafsir Abkam, Beirut: Dar El Kotob, 2000.

Anwar, Rully Khairul, Neneng Komariah, and M. Taufiq Rahman. "Pengembangan Konsep Literasi Informasi Santri: Kajian di Pesantren Arafah Cililin Bandung Barat." Wawasan: Jurnal Ilmiah Agama dan Sosial Budaya 2.1 (2017): 131-142. 
ARTIKEL

Chaplin, J.P. Kamus Lengkap Psikologi, Jakarta: PT Raja Grafindo Persada, 1995.

Echols, John M. "dan Hasan Shadily." Kamus Inggris-Indonesia, Jakarta: PT Gramedia Pustaka Utama (2003).

Garaudy, R. Islam Fundametalis dan Fundamentalis Lainnya.

Griffin, D.R. God and Religion in The Postmodern World, SUNY series: Construction Postmodern, US: 1988.

Hamka, Tafsir Al Az̧har,QS.Al Kaafirun satu s.d akhir, Jakarta: Pustaka Kalam.edisi baru 2013.

Kamus Besar Bahasa Indonesia Edisi Ketiga, vol. 1.thn.2002.

Karen Amstrong dalam, "The Battle for God: Fundamentalisem in Judaism Christianity and Islam, (London: Harper Collins Publisher,2000).

Katsir, Ibnu. Tafsir Al Qur'anul Az̧bim, Dar El Qohiroh,2000.

Kelsen, Hans. Pure Theory of Law in The Land of The Legal, Munich:Verlagsund Universitatsbuchandlung,thn.2010.

Mar'at, Sikap Manusia, Perubaban serta Pengukurannya, Bandung, Ghalian. thn.1981.

Pelto, Pertti J.Anthropological Research: The Structure of Inquiry, Harper \& Row Social Science, New York and London,thn.1970.

Pikiran Rakyat, Harian Umum, 15 Mei 2018.

Purwanto, M.Ngalim. Psikologi Pendidikan, Bandung: PT. Remaja Rosda Karya,1990

Rahman, M. Taufiq, and Beni Ahmad Saebani. "Membangun gerakan inklusivisme model jamaah Persatuan Islam." TEMALI: Jurnal Pembangunan Sosial 1.1 (2018): 58-72.

Republika, Harian Umum, 15 Mei 2018.

Rifai \& Chatarina Tri Anni, Psikologi Pendidikan, Semarang: UNNES,thn.2009.

Shepard, William E. Islam and Ideology: Toward A Typology, International Journal of Middle East Studies, vol.19, no.3 1987.

Subhan, Klasifikasi Ayat-ayat Hukum dari Segi Qoth'i dan Džbonni, Jurnal STAIN Samarinda,vol.I,thn.2012.

Syah, Muhibbin, Psikologi Pendidikan, (Bandung:PT Remaja Rosdakarya, 2011.

Syarifudin, Amir. Hukum Perkawinan Islam di Indonesia, Bandung: Mizan, thn.2002.

Walgito, Bimo. Psikologi Sosial Suatu Pengantar, Yogyakarta: Fakultas Psikologi UGM,thn.1994.

Watt, William Montgomery. Islamic Fundamentalism and Modernity terjemahan yang beredar di Indonesia berjudul Fundamentalisme Islam dan Modernitas, Jakarta: Penerbit.Raja Grafindo Persada, thn.1997).

Wijaya, Aksin. Dari Membela Tuhan ke Membela Manusia; Kritik atas Nalar Agamaisasi Kekerasan, Bandung: PT Mizan Media Utama, 2018. 
ARTIKEL

Zaidan, Abdul Karim. al-Wajir fi Ushul al-Fiqh, Baghdad: Dar El Qohiroh, 2005.

Zeidan, David. The Resurgence of Religion: A Comparative Study of Selected Themes ini Christian and Islamic Fundamentalist, Discourses, Brill: Boston. 2003.

\section{Website, Dokumen \& Wawancara:}

Dokumen resmi Hidayatullah yang diserahkan oleh pihak pesantren.

KH.Endang Lc pimpinan pondok Pesantren Tahfizhul Qur'an Hidayatullah ketika peneliti wawancarai.(red.18/07/2018).

Website: www.kominfo.go.id, dengan judul "BNPT minta Kominfo Blokir 22 Situs Radikal". 